\title{
Apparition: Aesthetics of Disproportion in Levinas and Adorno
}

In memory of Werner Hamacher

\section{The Question of Apparition}

Levinas and Adorno explore the question of apparition as the mode of being of the work of art, Levinas approaching the question as an intrinsic problem, Adorno considering it in addition with explicit reference to Benjamin. In reflections on Max Picard, Levinas writes that encountering what is "an apparition, but strangely real" is "perhaps the very definition of a poetic experience."1 Adorno determines in his Ästhetische Theorie: "Not the least of the difficulties of art today is that it is ashamed of apparition without being able to divest itself of it. Having become transparent to itself in its constitutive appearing, considering this appearance in its transparency as untrue, art gnaws at its own possibility, no longer being, in Hegel's language, substantial."2 The disruptive force that can emerge in apparition is elicited by Levinas and Adorno from these forms of tension. In the manner in which they work through the central theme "apparition", the lineaments and the limits of the critical affiliation in their thought with respect to art can be discerned. Levinas's use of the term is intimately linked to the phenomenological exploration of the problem of the phenomenon. Adorno is both cognisant of this context and responsive to Benjamin's discussion of the phenomenon and appearance in his Ursprung des deutschen Trauerspiels, "Goethes Wahlverwandtschaften", and other writings.

Both Levinas and Adorno emphasise the need for the philosophical accompaniment to the work of art. In one of the "Paralipomena" to his Ästhetische

1 “[. . .] une apparition, mais étrangement réelle. C'est là peut-être la définition même d'une expérience poétique." (Levinas 1976, 111). The article "Max Picard et le visage" is based on a lecture Levinas gave in 1966.

2 "Unter den Schwierigkeiten von Kunst heute ist nicht die letzte, daß sie der apparition sich schämt, ohne sie doch abwerfen zu können; sich selbst durchsichtig geworden bis in den konstitutiven Schein, der ihr in seiner Durchsichtigkeit unwahr dünkt, nagt sie an ihrer Möglichkeit, nicht länger, nach Hegels Sprache, substantiell.” (Adorno 1990, 127). 
Theorie, Adorno writes "Every work of art needs, in order to be experienced fully, thought and thus philosophy, which is thought that does not allow itself to be reined in." ${ }^{3}$ Levinas refers to this thought in his article "La réalité et son ombre" of 1948, as "critique". He carries out a rapprochement between the critical enterprise and philosophy in his article "Intentionalité et métaphysique" of 1959, where he connects the evocation of non-objectifying intentionality in Blanchot's critical writings with its use in contemporary philosophy of art. He writes of this aspect of Blanchot: "literature is not the approach towards ideal Beauty, not one of the ornaments of our life, not the witness to an epoch, not the translation of its economic conflicts, but the ultimate relation with being in an anticipation, almost impossible, of what is no longer being". ${ }^{4}$ It is this opening of literature to that which is "no longer being" that Levinas interprets in his own thought, particularly in his later work, as the site of the oscillation to which he refers as "clignotement". In this blinking between being and that which goes beyond it, "the ontological proposition remains open to a certain reduction, disposed to unsay itself and to mean in a completely different way." This "completely different" meaning is opened for Levinas in the relation to the other that enacts the radical unsettling of ontology.

Critique for Levinas elicits the trace of that which coagulates into the Said, into the work frozen in time, but which is beyond the being of the coagulated. In following the trace by means of non-objectifying thought, as he underlines in his endorsement of Blanchot's critical writing, the resulting discourse nevertheless remains open to a community of actual or potential interlocutors. For Adorno, critique is "necessary for works of art"; ${ }^{6}$ it deciphers the spirit constituting the process in which the tensions of the work's elements become manifest, and it goes beyond the aesthetic configuration to the spirit, Geist, which is its truth-content. The moment of apparition is the rupture of the objective form that cannot contain the spirit. Both for Levinas and for Adorno the work of art as apparition is a tension that points beyond itself. Levinas uses critique to

3 "Jedes Kunstwerk bedarf, um ganz erfahren werden zu können, des Gedankens und damit der Philosophie, die nichts anderes ist, als der Gedanke, der sich nicht abbremsen läßt.” Ibid., p. 392.

4 “[. . . ] la littérature n'est ni l'approche du Beau idéal, ni l'un des ornements de notre vie, ni le témoignage de l'époque, ni la traduction de ses conflits économiques, mais la relation ultime avec l'être dans une anticipation, quasiment impossible, de ce qui n'est plus l'être [. . .]." (Levinas 2010, 199).

5 "[. . .] la proposition ontologique reste ouverte à une certaine réduction, disposée à se dédire et à se vouloir tout autrement dite.” (Levinas 1986),. The article "Façon de parler” was first published in 1980.

6 "Darum ist Kritik den Werken notwendig." (Adorno 1990, 137). 
show that the phenomenon of the work of art is an enigma. Adorno determines that manifestation is in itself a negation: "If the spirit of works of art shines forth in their sensuous appearance, it shines forth only as their negation, in union with the phenomenon and at the same time its Other. The spirit of works of art adheres to its form, but it is only spirit if it points beyond it."7 Both the enigma and the negation are movements that put the being coagulated in the work of art into question.

\section{Levinas: Disproportion, Ethics, and the Work of Art}

For both Levinas and Adorno, apparition is an event that contains a paradoxical movement of presentation and dissolution, a tension within appearance itself. In apparition, the phenomenon is turned against itself in the noncoincidence to which Levinas refers as "anachronism". This is the "pure passage" of the other as "trace". The manner in which the trace disturbs the phenomenon as its interruption, the disruption of the phenomenon by that which cannot appear, is explored by Levinas under the title of the "enigma". His examination of the irruption of "expression" in the phenomenon, interrupting its "indiscreet and victorious appearance", 8 is part of his exposition of the "face", the proximity in which the other is approached. This is the context in which, for example, he considers poetry in his discussion of Agnon's writing. Levinas sets up a parallel to the relation between the phenomenon and relation in general. He determines the following: "It belongs to the essence of art to signify between the lines - in the intervals of time - between time - like a trace that would be anterior to the step or like an echo that would precede the repercussion of a voice." ${ }^{9}$ Levinas proposes a complement to this "anachronism" of a signifying whose meaning is always before, this

7 "Leuchtet der Geist der Kunstwerke in ihrer sinnlichen Erscheinung auf, so leuchtet er nur als ihre Negation, in der Einheit mit dem Phänomen zugleich dessen Anderes. Der Geist der Kunstwerke haftet an ihrer Gestalt, ist aber Geist nur, insofern er darüber hinausweist." Ibid.

8 "l'apparoir indiscret et victorieux". (Levinas 1990, 291). The article "Enigme et phénomène" was first published in 1965.

9 “Il appartient à l'essence de l'art de signifier entre les lignes - dans les intervalles du temps - entre temps - comme une trace qui serait antérieure à la marche ou comme un écho qui précéderait le retentissement d'une voix." (Levinas 1976, 12). The article "Poésie et resurrection" was first published in 1973. 
side of the thematic object of a sign, of an indication. The complement is exegesis. Already in his article "Réalité et son ombre" Levinas had determined critique as the activity that returns the representation of reality frozen in an image - the idolatrous doubling that binds sensation in a rhythm constituting an ontological dimension of its own - to discourse open to the community with others. The perspective of the relation to the other in the philosophy of art is the final, named but as yet unexplored dimension of the exegesis envisioned in this early text. Here he writes that "being could not be said in its reality, that is in its time" 10 without this widened perspective. The analysis in Levinas's text Le temps et l'autre, consisting of lectures of 1946/7, underlies this position of the saying of being, reality, and time depending on the other, and it is here that he takes the further step indicated in "Réalite et son ombre". In these lectures, as elsewhere in his work, for example in De l'existence à l'existant, he returns repeatedly to Shakespeare, writing that "it sometimes seems to me that all philosophy is nothing but a meditation of Shakespeare"11 and citing Macbeth and Hamlet to show respectively the hypostase of liberty in the present moment and the impossibility of assuming death into a present. Levinas states that Hamlet is a "lengthy testimony"12 to the latter theme. He invokes these literary works as part of his development of this theme to the thought on sexuality and paternity with which his lectures approach alterity and sociality. The perspective of the relation to the other as testified by literature is central to his meditation on Agnon of 1973, where he takes up his earlier critique of the image and his earlier concern about the responsibility he sees abrogated in aesthetic transport now, however, in the context of responding to an alterity "wholly other than being" $" 13$ by means of non-objectifying thought.

At the end of his article "La poésie et l'impossible" of 1969, one of his several discussions of Paul Claudel's writing, Levinas poses a series of questions that mark the coordinates of his own thought on literature. He asks whether politics constitutes the ultimate horizon of being and the guide of action. Stating that there is a "poetic vision" that transcends politics, he asks whether poetry is condemned to being "belles lettres" and to "perpetuating fantasms". Finally, he asks whether "contrary to this" it is not "the very definition of

\footnotetext{
10 "perspective [. . . ] sans laquelle l'être ne saurait être dit dans sa réalité, c'est à dire dans son temps". (Levinas 1994, 148).

11 “[. . . ] il me semble parfois que toute la philosophie n'est qu'une méditation de Shakespeare." (Levinas 1983, 60).

12 "un long témoignage", Ibid., 61.

13 "tout autre que l'être”. Emmanuel Levinas, "Poésie et résurrection", 14.
} 
poetry" to be what "makes language possible". ${ }^{14}$ As the very possibility of language, as a Saying that demands exegesis, poetry signals the "[i]mpossibility of remaining silent"15 that is the responsibility of those who have survived the historical event that cast the Jews "into the most profound depths of the abyss into which all humanity was thrown between 1939 and 1945". ${ }^{16}$ Levinas's thought on art addresses an enigma. On the one hand, as in the articles that compose the volume Difficile Liberté, where Judaism is explored in multiple ways as "the substitution of the letter for the soil", ${ }^{17}$ he emphasises the commitment this entails to "creating a type of man who lives in a demystified world, freed from enchantment". 18 This position militates against art, both as the pagan rootedness in the earth that Levinas invariably links to Heidegger and in the versions of petrification, of role-fulfilment, of figure that, for example, he identifies in Claudel's Christian images of sacred history and that he contrasts with the liberty of the human as person. ${ }^{19}$ The terms in which he invokes lucidity as against the intoxication of chthonic or religious rapture pertain in this perspective equally to art. This is the sense in which Levinas writes in Totalité et infini ${ }^{20}$ of the manner in which the "poetic activity", though - as he previously also underlined in his article "La réalité et son ombre" - "conscious", becomes transformed, suffused by rhythm, the artist being transported by the work or becoming the work itself in the Dionysian fashion evoked by Nietzsche. Here, in Totalité et infini, Levinas addresses the "rhythm that enraptures and abducts the interlocutors" and to this he opposes "prose" as the "discourse" that "is rupture and commencement". In contrast to the "enchantment by the rhythm" that "envelops" and "cradles" the activity in question, Levinas emphasises the prosaic disruptive interruption of such enrapturing distortion that imposes a

14 "Mais la politique constitue-t-elle la trame ultime de l'être et le guide unique de l'action? La vision poétique qui la transcende est-elle à jamais vouée à demeurer 'belles lettres' et à perpétuer les fantasmes? N'est-elle pas au contraire - et c'est probablement la définition même de la poésie - ce qui rend le langage possible?” (Levinas 1976, 204). 204.

15 "Impossible de se taire. Obligation de parler." Ibid.

16 “au plus profond de l'abîme où, entre 1939 et 1945, fut jetée l'humanité.” Ibid., 200.

17 "la substitution de la lettre au sol". (Levinas 1976, 211). The article "Simone Weil contre la Bible" was first published in 1952.

18 "créer un type d'homme qui vit dans un univers démystifié, désensorcelé". (Levinas 1976, 90). The text "L'arche et la momie" was presented at a round table discussion broadcast on radio in 1958.

19 See “Personnes ou figures (À propos d'Emmaüs' de Paul Claudel)”, Ibid., p. 185. The article was first published in 1950.

20 "rythme qui ravit et enlève les interlocuteurs"; “charme du rythme”; “envelopper”; "bercer”. (Levinas 1980, 221). 
role on the poetic "initiative". The freedom at issue, defended against the manner in which "influences surge forth unbeknownst to us", ${ }^{21}$ is formulated in this passage in Totalite et infini in a manner that clearly echoes Levinas's critique of Claudel, where he wrote more than twenty years earlier: "We distrust the poetry that already rhythmically imbues and puts a spell on our gestures, all that which, in lucid life, is at play in spite of us."22

Already in one of Levinas's early articles, however, in "De l'évasion", published in 1935, he presents another possibility, which opposes the aspect of appearance that seduces the producers and the recipients of, the participants in, the work of art. Here, he examines the theme of escape from oneself, the need to "break the most radical, the most indispensible chain there is, the fact that the ego is itself'. ${ }^{23}$ This theme, which, he states, is prevalent in contemporary literature, opens onto fundamental philosophical questions, above all that of being as being. Levinas designates with the term of "excendance" the need experienced by the human being to escape imprisonment in being, to be extricated from being fused to oneself. He examines in this context the feelings of shame and nausea, both of which force the self into being itself while wanting to escape itself. Levinas writes here of the nudity to which the self is reduced, a nudity that is "the very experience of pure being". ${ }^{24}$ In situating the human being in this experience, Levinas writes of shame that it is "one and the same as nausea" ${ }^{25}$ Here, he determines the importance of Céline's work Voyage au bout de la nuit. Sartre, with whose novel La nausée Levinas's essay shares central themes, was to preface his text precisely with a quote from Céline's Voyage. Levinas writes "What is of great interest in Voyage au bout de la nuit by Céline is to have divested the universe, in a sad and desperate cynicism, thanks to a marvellous art of language." ${ }^{26}$ Here, the enigma of art is brought to the fore. Céline's language is "marvellous" but in such a way that it breaks through the

21 “où des influences surgissent, à notre insu”. Ibid., 222.

22 "Nous nous méfions de la poésie qui déjà scande et ensorcelle nos gestes, de tout ce qui, dans notre vie lucide, se joue malgré nous." "Personnes ou figures", 188.

23 "le besoin de sortir de soi-même, c'est à dire de briser l'enchaînement le plus radical, le plus irrémissible, le fait que le moi est soi-même." (Levinas 1982, 98).

24 "l'expérience même de l'être pur", Ibid., 116.

25 "Le phénomène de la honte de soi devant soi [. . . ] ne fait qu'un avec la nausée.” Ibid., 117.

26 "C'est le grand intérêt du Voyage au bout de la nuit de Céline que d'avoir, grâce à un art merveilleux du langage, dévêtu l'univers, dans un cynisme triste et désespéré." Ibid., 112. In his article "Langage quotidien et rhétorique sans éloquence" of 1981, Levinas discusses Céline in the context of "anti-literature" and of "anti-humanism", stating that his work was "perhaps a signal" (peut-être [. . .] le signal" of the former and that this "anti-literature" was a reason for the latter. (Levinas 1987, 190). 
vestments with which the nudity of being is concealed. It is noteworthy that Levinas underlines this function of Céline's writing in the Voyage, in which "sad and desperate cynicism" serves to reveal the harsh and sordid reality of war, colonialism, urban poverty, and human relations in general, where the figures representing the good are unlikely beacons of hope both acknowledged as such and invariably betrayed by the narrating figure. The good is given unconditionally, however incapable the recipient is of responding adequately to it. The novel is enigmatic because the narrating figure both breaks through the images governing social reality and the self while himself succumbing to his own distorting abrogation of responsibility. In one of the most powerful episodes, the narrator, a doctor in an impoverished quarter of Paris, leaves a young woman, who is bleeding to death as the result of a backstreet abortion, to the mercy of her parents, who in their egotistical moral hypocrisy refuse to call for an ambulance because they are only interested in saving face with respect to their neighbours. The historical circumstances of the Voyage differ - notoriously from those of Céline's later writing. While the style of Nord, for example, is still that of "sad and desperate cynicism" and there is still a ductus of unveiling, the narrator is a self-proclaimed "collabo" on the run and the milieu described is that of other collaborators and proponents of National Socialism facing the end of the regime they had celebrated and supported. The self-understanding of the narrator as collaborator is thematised in a dialogue that prefaces one of the chapters, where an unidentified voice asks him, whether he indeed calls himself a narrator, and when he affirms that he does, he is asked whether he does not feel shame in doing so. It is left open whether this shame should be felt by the instance that claims to frame a narrative as such, i.e. that claims a narrative is at all possible when facing contemporary reality, or rather one concerning the specific events involving the narrator and his fellow collaborators. The evaluation of the extent to which the narrator's tone of aggrieved self-pity should be regarded as part of the stripping away of concealing vestments or rather as further concealment using the style and language of such an unveiling is central here. In the terms of "De l'évasion" only the former would be acceptable. These terms are confirmed in the sustained reflection on the role of literature and of art in general with regard to its representation of reality found in Levinas's article "La réalité et son ombre". ${ }^{27}$

27 The importance of this text for Levinas's thought has been underlined by commentators such as Hent de Vries, in a chapter on Levinas and art added to the new, English language edition of his book Theologie im pianissimo: Zur Aktualität der Denkfiguren Adornos und Levinas' (1989), Minimal Theologies. Critiques of Secular Reason in Adorno and Levinas (de Vries 2005), Fabio Ciaramelli, in his article “L’appel infini à l'interprétation. Remarques sur 
The question of the relation of philosophy to literature in Levinas's work often emerges from passages such as the following sequence of thoughts in the text "Signature", with which Difficile Liberté ends. Levinas delineates here the way in which the experience of the other is "expérience par excellence". His preface to Totalité et infini of 1961 had already indicated with this expression that the conception of the experience involved in his thought on alterity is problematic since there could be no experience, at least no "objective experience", of the infinite, of that which is always exteriority. This means, he stated, that one should speak of "the relation to the infinite in other terms than those of objective experience." 28 The expression "expérience par excellence” is employed by Levinas to designate this other experience, the experience of the other. In his article "La trace de l'Autre" of 1963, Levinas explores the theme of "the heteronomous experience" 29 as a "movement without return", one "of the Same towards the Other that never returns to the Same." 30 Since the status of experience qua experience is always in question, ${ }^{31}$ the terms in which Levinas refers to it are accompanied by a displacing of the objectifying tendency that, according to his claim, characterises occidental philosophy. This displacing is active in Levinas's critique of the general application of Husserlian intentionality in its noetic-noematic structure, of the, in his view, cognitive structure of Heideggerian fundamental ontology, and indeed of Buber's conception of the

Levinas et l'art" (Ciaramelli 1994), and Jacques Colleony in his article "Levinas et l'art: La réalité et son ombre" (Colleony 1991).

28 “[. . . ] il faudra dire la relation avec l'infini en d'autres termes qu'en termes d'expérience objective. Mais si expérience signifie précisément relation avec l'absolument autre - c'est-àdire avec ce qui toujours déborde la pensée - la relation avec l'infini accomplit l'expérience par excellence." (Levinas 1980, XIII).

29 "l'expérience hétéronome”. (Levinas 2010, 266). The article was first published in 1963.

30 “un mouvement du Même vers l'Autre qui ne retourne jamais au Même.” Ibid., 266-267.

31 It is in question to such an extent that Levinas writes in "Éthique et l'esprit", an article published in 1952, "the vision of the face is not an experience, but an exit from oneself" ("la vision du visage n'est pas une expérience, mais une sortie de soi”). (Levinas 1976, 26). In this text, Levinas formulates the thought on the impossibility of murder that later constitutes one of the most challenging passages in Totalité et infini. Murder is impossible, he states. Yet, he continues, "in reality murder is possible. But it is possible when one has not looked the other in the face. The impossibility of killing is not real, it is moral.” (“[. . .] en réalité, le meutre est possible. Mais il est possible quand on n’a pas regardé autrui en face. L'impossibilité de tuer n'est pas réelle, elle est morale." Ibid., 26. This is why he writes that "the vision of the face is not an experience" for what he will later emphatically characterise as going beyond ontology is at stake. The question of disproportion and its implications for ontology is already present at this point of Levinas's thought. 
experience of alterity. The steps Levinas takes in "Signature" proceed via determinations of disproportion. Just as the idea of infinity Descartes introduced in the third Méditation "overflows", déborde, the thought presented in the Cartesian theory of the mind, "the Other is out of proportion to the power and the freedom of the Ego". ${ }^{32}$ The characterisation of disproportion Levinas undertakes connects this determination to ethics: "The disproportion between the Other and the Ego is precisely ethical consciousness." 33 The next two steps that he takes distinguish "ethical consciousness" first from an "experience of values" and second from a "modality of psychological consciousness". He contrasts ethical consciousness with the first as "an access to external being" and with the second "the condition and, first of all, even inversion" of such a psychological consciousness. To experience the Other means "that the freedom that lives by consciousness inhibits itself in front of the Other". ${ }^{34}$ Both are forms of exteriority. The Other is, Levinas underlines, "external being par excellence". ${ }^{35}$ This external being calls the force, the spontaneity of the Ego into question. The Other as the face is the calling into question of the joyous force of this spontaneity. Levinas's final move here is to cite two passages from literature, the first from Tolstoy's War and Peace and the second from Pushkin's Boris Godounov, which embody this experience of the face, the experience par excellence.

Levinas's elucidation of this experience, which is "fundamental", he states, because it is supposed by objective experience, takes place both in discursive concepts, of which Totalite et infini is the systematic presentation, and with reference to literature. The question is whether the literature that Levinas cites here and elsewhere, for example in his adducing of Sonia Marmeladova's “insatiable compassion” for Raskolnikov in Dostoyevsky's Crime and Punishment, ${ }^{36}$ is a mere illustration of what he otherwise expounds using discursive, conceptual means or whether the "disproportion" invoked above can be experienced on literature's own terms.

32 “[ . . ] Autrui est hors proportion avec le pouvoir et la liberté du Moi.” (Levinas 1976, 437).

33 "La disproportion entre Autrui et le Moi - est précisement la conscience morale." Ibid.

34 "[. . . ] la liberté qui vit par la conscience s’inhibe devant Autrui.” Ibid.

35 "l'être extérieur par excellence". Ibid.

36 "Désir d'Autrui”. Levinas, "La trace de l’Autre”, 270. 


\section{Adorno: Aesthetic Immanence and the Configuration of Transcendence}

In Adorno's inaugural lecture at the University of Frankfurt, “Die Aktualität der Philosophie" of 1931, the terms in which he develops the guiding idea of "interpretation", Deutung, pertain to the movement from the theoretical to the practical attitude towards the world. Adorno invokes the idea of dialectics here, which, he underlines, is the necessary condition for philosophical Deutung. He states in lapidary fashion: "The interpretation of the reality that obtains and its suspension are in a mutual relation. Reality is not, however, suspended in the concept; but from the construction of the figure of reality follows promptly the demand for real change to it." 37 The acquaintance with reality does not "remain within the closed space of knowledge"38 but is "imparted", erteilt, by "Praxis". This is the trajectory from Adorno's initial determination that there is an "essential connection" 39 between "interpretative philosophy" and materialism. Adorno's conception of philosophy as he outlines it in his exposition of the idea of Deutung is opposed to the claim of idealism that "reality is founded in the ratio" and that tracing back to the primary axioms of autonomous rational laws would enable the rational architectonic of being to be established. In contrast to this, philosophy has to respond to the "irruption of the irreducible". 40 Being breaks through the autonomous rational imposition of laws. It interrupts the movement back to first principles and forces thought to confront the concrete historical moment. Adorno conceives a dialectical philosophy here that responds to the "force of reality" in the form of the essay. His delineation of this philosophy develops the position he maintained in his critique of Kierkegaard's aesthetics in his work Kierkegaard. Konstruktion des Ästhetischen of 1933, the published version of his Habilitationsschrift of 1931. In contrast to Kierkegaard's claim that abstracting from what is historically specific and attaining what is temporally invariant constitutes the immortality of the most distinguished works of art, Adorno emphasises precisely the historically particular. He writes: "Works of art do not obey the force of the generality of ideas. Their centre is the

37 "Die Deutung der vorgefundenen Wirklichkeit und ihre Aufhebung sind aufeinander bezogen. Nicht zwar wird im Begriff die Wirklichkeit aufgehoben; aber aus der Konstruktion der Figur des Wirklichen folge allemal prompt die Forderung nach ihrer realen Veränderung.” (Adorno 1969, 338).

38 "im geschlossenen Raum von Erkenntnis". Ibid.

39 "wesentliche[r] Zusammenhang"; “deutende[. . .] Philosophie”. Ibid.

40 "Einbruch des Irreduziblen”. Ibid., 343. 
temporal and the particular, to which they orientate themselves as its figure; whatever they mean beyond this, they mean solely in the figure." 41

This position is developed in its linguistic, logical, and ontological ramifications in Adorno's Ästhetische Theorie. He connects Benjamin's thoughts on the "intensive direction of expression into the core of innermost muteness" 42 with the final section of Wittgenstein's Tractatus and delineates the dialectical structure that determines the relation of the particular and the general in the work of art. This latter is closest to the universal, he underlines, the closer it comes to language. The mimetic dimension of the work of art is that aspect in which it is similar to language. However, the work gains its "general loquacity" 43 in its specificity, the further away it is from the general. The work of art both says and does not say the general. This paradox lies in the fact that "being opaque and specific, the mimetic instance through which it says it at the same time opposes the saying". 44

In Adorno's address “Die Aktualität der Philosophie”, he delineates a kind of thinking that responds to the collapse of what philosophy had hitherto assumed, i.e. "that it is possible to grasp the totality of reality through the power of thought". ${ }^{45}$ This assumption, he states, is revealed as illusory, at worst deceptive ideology, by a reality whose "order and form" 46 defeat any "claim of reason"47 to encompass it. In terms whose proximity to Benjamin, to whom Adorno planned to dedicate the published version of the address, is not fortuitous, Adorno points to the "traces and ruins", which are the only aspects of this reality in which "it permits the hope that it will at some time become right and just". ${ }^{48}$ Adorno begins his address by pointing to a kind of thought that seeks out and follows these "traces and ruins" and ends his exposition of this idea of philosophy by characterising its power to "explode the measures of the mere

41 "Kunstwerke gehorchen nicht der Macht der Allgemeinheit von Ideen. Ihr Zentrum ist das Zeitliche und Besondere, auf welches hin sie als dessen Figur sich ausrichten; was sie mehr bedeuten, bedeuten sie einzig in der Figur.” (Adorno 1979, 34).

42 "die intensive Richtung der Worte in den Kern des innersten Verstummens hinein". (Benjamin 1966, 126-127), quoted in Adorno 1990, 305.

43 "beredt allgemein". Ibid.

44 "[. . .] daß jenes Mimetische, durch welches sie es sagt, als Opakes und Besonderes dem Sagen zugleich opponiert." Ibid.

45 “[. . .] daß es möglich sei, in Kraft des Denkens die Totalität des Wirklichen zu ergreifen.” (Adorno 1969, 325).

46 "Ordnung und Gestalt". Ibid.

47 "Anspruch der Vernunft”. Ibid.

48 “ [ . . ] sie nur in Spuren und Trümmern die Hoffnung gewährt, einmal zur richtigen und gerechten Wirklichkeit zu werden.” Ibid. 
existent”. In both cases, at the beginning and at the end, the thought he espouses is set against philosophy's previous claim to totality, be it that of German Idealism or of Heidegger's phenomenological fundamental ontology, Adorno's initial account of the presumption of Idealism with regard to reality being developed into a parallel critique of the presumption of fundamental ontology with respect to Being. This is responsible for the terms in which he formulates his final characterisation of the thought he has in view in contrast to such presumption: "For spirit is indeed not capable of producing or grasping the totality of reality; but it is capable of penetrating in miniature, to explode in miniature the dimensions of the merely existent." 49 The thought Adorno conceives here is concerned with the concrete. That which he denominates as "interpretation", Deutung, is contrasted with research, Forschung, which is what the individual empirical sciences undertake. The former bears, he determines, an affinity to materialism, the "kind of thought" that "most rigorously rejects the idea that reality is intentional or significant". ${ }^{50}$ The thought Adorno calls Deutung is faced with the fact that the symbolic constructs of philosophy have lost their power to give meaning to the world. He regards this thought as having an affinity to materialism inasmuch as it distances itself from the "'meaning' of its objects" 51 and no longer itself refers to "implicit [. . .] meaning", 52 an example of which, he states, would be that of religion. The emphasis on the concrete is related intimately to this. Since the "symbolic function", ${ }^{53}$ in which the particular represented the general in Idealism, has collapsed, any reference to totality is no longer to be found in symbolic representation of the "total question", ${ }^{54}$ but "in a concrete diagnosis of an individual case". ${ }^{55}$

Adorno characterises the work of art in an early version of the Introduction to his posthumously published work Ästhetische Theorie as the "crystallisation" of a "process" and contrasts this with its attributes as an existent, Seiendes. This determination forms a central aspect of his delineation of the role of the work of art in negating the regnant state of the world. It is in this negation, he maintains, that the work of art constitutes itself as spirit, Geist. This

49 "Denn wohl vermag der Geist es nicht, die Totalität des Wirklichen zu erzeugen oder zu begreifen; aber er vermag es, im kleinen einzudringen, im kleinen die Maße des bloß Seienden zu sprengen. Ibid., 344.

50 “[. . .] Art von Denken [. . .], die die Vorstellung des Intentionalen, des Bedeutenden von der Wirklichkeit am strengsten abwehrt”. Ibid., 336.

51 “'Sinn' seiner Gegenstände”. Ibid.

52 "impliziten [. . .] Sinn”. Ibid.

53 "symbolische Funktion". Ibid.

54 “totale Frage”. Ibid.

55 "in einem konkreten Befund". Ibid. 
constitution is dialectical construction, Adorno writes, "inasmuch as" spirit informs it. The character of the work of art as process manifests itself here: "Works of art, as much as they appear to be existents, are crystallisations of the process between that spirit and its other." ${ }^{26}$ In the later Introduction to the last version of the Ästhetische Theorie, he emphasises the task of "interpretation", Deutung, with respect to art as an activity that follows the latter's movement in its relation to its other: "Art can only be interpreted in the law of its movement, not through invariants. It determines itself in relation to what it is not."57 Adorno emphasises the contrast between this characteristic and the central contention of Hegel's aesthetics, i.e. the positing of the exteriorisation of the spirit as at the same time the recognition of its identity with this exteriorised other. For Hegel, the movement of self-alienation and self-recognition as identity takes place within the totality of spirit. In contrast to this, Adorno reveals the rupture that the dissolution of this "Generalthesis" - as he puts it, using the term from Husserl's seminal inauguration of transcendental phenomenology, the Ideen of 1913 - implies for the work of art. If spirit can no longer be seen as reincorporating its self-alienation as exteriority into a totality, it constitutes only a part of the work of art and is inextricably related to the other as the "historically and socially preformed" materials and procedures that the work of art bears within itself as the heterogeneous moments that resist unity. The tension between this resistance and the striving for unity is what is manifested as dissonance. Adorno underlines the unstoppable, unaufhaltbare, movement in the history of art that has come to make dissonance its centre. His following determination is crucial. In this dissonance he sees a participation in suffering. In the unity of the process at work in art, he discerns the attempt of suffering to be expressed in language. The terms he employs here are graphic: "to feel its way to language". ${ }^{58}$ Dissonance and suffering are linked in expression.

In Adorno's determination that "expression can hardly be imagined as anything other than that of suffering", which in the immanence of the work of art "resists immanence under the law of form", 59 making expression into "the

56 "Die Kunstwerke sind, mögen sie noch so sehr ein Seiendes scheinen, Kristallisationen des Prozesses zwischen jenem Geist und seinem Anderen.” (Adorno 1990, 512).

57 "Deutbar ist Kunst nur an ihrem Bewegungsgesetz, nicht durch Invarianten. Sie bestimmt sich im Verhältnis zu dem, was sie nicht ist.” Ibid., 12.

58 "zur Sprache tastet”. Ibid., 512.

59 "Läßt Ausdruck kaum anders sich vorstellen denn als der von Leiden [. . .], so hat Kunst am Ausdruck immanent das Moment, durch welches sie, als eines ihrer Konstituentien, gegen ihre Immanenz unterm Formgesetz sich wehrt." Ibid., 168-169. 
lamenting face of works", ${ }^{60}$ porous in their dissonances to alterity, there is a proximity to Levinas's thought. In the section "Visage et éthique" in Totalité et infini, Levinas explicates the idea of expression as the revelation of infinity in the face of the other. In sub-section 2, Levinas follows the question of the disproportion between infinity and the capacity of the subject to the point at which he exposes infinity as "the original expression" ${ }^{61}$ For Levinas, the question of apparition is intimately linked to the question of being. This is, in turn, inextricably connected to the theoretical attitude, which he views as predominant in occidental philosophy. The point at which Levinas's own trajectory begins concerns the question of whether all meaning is restricted to this relation. He puts this succinctly in his lecture-series "Dieu et l'onto-théologie" of 1975/ 76, where he writes: "One can ask oneself, however, whether the manifestation where all signification has the form of an ontological event exhausts the meaning of the signification, whether everything is exhausted by this form." ${ }^{2}$ In this late adumbration of Levinas's thought, where he seeks to "inscribe a dis-quiet", 63 to think language as a questioning of the priority of ontology, as the question of whether all meaning derives from being, apparition is firmly situated at the point at which being "makes itself into presence in a consciousness" ${ }^{64}$ and thereby affirms itself.

Levinas characterises the primary focus of occidental philosophy repeatedly as "the apparition of a given content" ${ }^{\text {" }}$ represented in the signification of the Said and communicated to others as such. The sense of signification, he determines, is "a way of representing being in the absence of being" ${ }^{66}$ Apparition of a given fulfils signification. The task Levinas sets himself is to seek a signification that does not achieve its end in ontology. This he finds in the responsibility for the other, which he explicates in his later thought in a series of ever more emphatic locutions for the "nudity" this involves for the subject exposed to the other. This hyperbolic intensification results in passages such as the following, the language of which borders on provocation: "In this responsibility,

60 "Ausdruck ist das klagende Gesicht der Werke.” Ibid., 170.

61 "Cet infini, plus fort que le meutre, nous résiste déjà dans son visage, est son visage, est l'expression originelle, est le premier mot: 'tu ne commettras pas de meutre'." (Levinas 1980, 173).

62 "Mais on peut se demander si la manifestation où toute signification a la forme d'un événement ontologique épuise la signifiance de la signification, si tout est épuisé par cette forme." (Levinas 1993, 187).

63 "inscrire une in-quiétude". Ibid., 148.

64 "se faire présence dans une conscience”. Ibid., 147.

65 "l'apparition du donné”. Ibid., 180.

66 "un mode de représentation de l'être en l'absence de l'être”. Ibid. 
the ego does not pose itself but loses its place, deports itself or finds itself deported. The substitution for the other is like the trace of exile and of deportation." 67 The Saying in which this takes place is the signification prior to that which appertains to the synchronisation in which the synthetic gathering of the temporal manifold is effected in transcendental apperception, in Kant's terms, or as the subjective pole of identification in the intentional relation to an object, in Husserl's terms. For Levinas, the Saying that is prior to the Said is, in contrast to what he understands as Kant and Husserl, diachronic. He determines that this Saying is to bear witness to Infinity, which cannot appear. In witnessing, he writes: "Infinity reveals itself without appearing, without showing itself as Infinity." 68 The disproportion between the way this witnessing relates to infinity, which Levinas names glory, gloire, is pre-temporal and pre-semantic. In the non-coincidence of the terms of the relation with the other, temporality that cannot be reduced to simultaneity and meaning that cannot be reduced to the concept are at play.

Expression and its role in opening up a passage to the other in a language prior to the language frozen in concepts is a central theme in Adorno's thought on the work of art. In the Ästhetische Theorie he analyses the aporetic situation of contemporary art, which, on the one hand, he regards as in danger of giving up its autonomy and succumbing to the "mechanism of existing society", 69 while, on the other hand, if remaining enclosed within itself, it risks being neglected and considered peripheral and thus "harmless". Here, he introduces a criterion of the excellence of the work of art. The fact that the contemporary work of art withdraws from communication is, he claims, merely the necessary condition for its refusal to comply with ideology. He determines that the "central criterion" of the "power of expression", Ausdruck, has to be added to this. The implications of this terminological and thematic use of Ausdruck are manifold and they concern the kind of speech that does without words. Adorno writes: "The central criterion is the power of expression, through the tension of which works of art become eloquent with a wordless gesture. In expression, they reveal themselves as social stigmata. Expression

67 "Dans cette responsabilité, le moi ne se pose pas, mais perd sa place, se déporte ou se trouve déporté. La substitution à l'autre est comme la trace de l'exil et de la déportation.” Ibid., 184.

68 "[. . . ] l'Infini se révèle sans apparaître, sans se montrer comme Infini.” Ibid., 229.

69 "Betrieb der bestehenden Gesellschaft." (Adorno 1990, 352). 
is the social ferment of their autonomous form." ${ }^{\text {"70 }}$ He cites Picasso's Guernica as the "chief witness", Kronzeuge, for this way in which form reveals the wounds of the world. When Adorno invokes the term "Ausdruck" in this passage, there are various contexts in which it could be understood. For one, it contains a reminiscence of the Leibnizian monad as the "expression" of the monadic community, an idea that is further transmitted to German Idealism via Shaftesbury and Herder. At the same time, he connects the term to that of "tension", Spannung, which could bear a relation to one of the central elements of the use of language and images in Expressionism. The closest connection to Adorno's thought, however, while retaining both of the latter contexts, is provided by Benjamin's use of the term in the epistemological convolute of the Passagen-Werk. Here, Benjamin writes in the fragment N1 a, 6 of his striving to construct the "relation of expression", Ausdruckszusammenhang, ${ }^{71}$ between the economy and culture, while in the fragment N 10 a, 3 he locates his conception of the "dialectical image" at the point "where the tension between the dialectical opposites is greatest."72 Adorno's judgement on Guernica emphasises its force in this respect, stating that the painting gains "that expression [. . .] that sharpens it into social protest beyond any contemplative misunderstanding while being strictly incompatible with realism by decree, precisely through inhuman construction". ${ }^{73}$ What is important in the current context is the conception of the "stigmata" as the wordless expression of social suffering.

This theme finds its concentrated formulation in the final sentence of the Ästhetische Theorie: "What kind of historiography would art be if it shook off the memory of accumulated suffering."74 Formally a question, the sentence is an expostulation that amplifies what he had earlier identified as "the character of art as

70 "Zentrales Kriterium ist die Kraft des Ausdrucks, durch dessen Spannung die Kunstwerke mit wortlosem Gestus beredt werden. Im Ausdruck enthüllen sie sich als gesellschaftliches Wundmal; Ausdruck ist das soziale Ferment ihrer autonomen Gestalt.” Ibid, 353.

71 (Benjamin, 1982, 573).

72 “[. . . wo die Spannung zwischen den dialektischen Gegensätzen am größten ist.” Ibid., 595.

73 "[. . .] bei strikter Unvereinbarkeit mit dem verordneten Realismus, gerade durch inhumane Konstruktion, jenen Ausdruck [. . .], der es zum sozialen Protest schärft jenseits aller kontemplativen Mißverständlichkeit.” (Adorno 1990, 353). This judgement may require further differentiation in the light of Carlo Ginzburg's discussion of Picasso's painting, which emphasises precisely its relation to the iconographic tradition. See Ginzburg Das Schwert und die Glühbirne. Picasso's 'Guernica' (Frankurt am Main: Suhrkamp, 1999.

74 "Was aber wäre Kunst als Geschichtsschreibung, wenn sie das Gedächtnis des akkumulierten Leidens abschüttelte.” (Adorno, 1990, 387). 
unconscious historiography". ${ }^{75} \mathrm{He}$ had explicated the latter expression as: "anamnesis of the defeated, repressed, perhaps possible."76 This historiographical character of the work of art is given an alternative formulation in one of the "Paraligomena" that accompany Adorno's unfinished text of the Ästhetische Theorie. The remembrance that takes place in the work of art is intimately connected with its form, indeed to such an extent that the existence of the latter depends on the former: "Even in a legendary better future art would not be permitted to deny remembrance of the accumulated horror, for otherwise its form would be nullified."77 "Form", when Adorno employs this term in his Ästhetische Theorie, is not set over against "matter" in an abstract opposition, as if it were imposed onto something inchoate. The role that both form and matter play in the work of art is rather dialectical, each of these basic aspects being mediated in the tension Adorno views as constitutive for the work's dynamic.

"Form" is a determining moment of the work's relation to the world. Adorno states this in lapidary fashion: "The unresolved antagonisms of reality return in works of art as the immanent problems of their form."78 He conceives this relation as one of question and answer. The work of art is in this sense an answer to the "interrogative form", Fragegestalt, of what impinges upon the subject's experience "from the outside", von außen. ${ }^{79}$ Experience is thus imbued with the process of question and answer, and in this process the answer given by the work of art itself becomes in turn a question. The task of the commentator, or of the philosophy of art, is to make this relation explicit. In "Voraussetzungen", an article on Hans Helms, which contains one of Adorno's most concentrated discussions of the philosophical implications of modern literature and art in general, he writes that the task of the commentator is to follow the "tensions that are sedimented in the work of art". He refers to what is implied by "the aesthetic concept of understanding" 80 as "a kind of tracing" 81 of these tensions that uses concepts but does not reduce the work by translating it into concepts.

Here, just as in "Die Aktualität der Philosophie", in his important article "Der Essay als Form”, and in his Ästhetische Theorie Adorno emphasises that

75 "Charakter der Kunst als bewußtloser Geschichtsschreibung”. Ibid., 384.

76 “[. . .] Anamnesis des Unterlegenen, Verdrängten, vielleicht Möglichen.” Ibid.

77 "Selbst in einer legendären besseren Zukunft dürfte Kunst die Erinnerung ans akkumulierte Grauen nicht verleugnen; sonst würde ihre Form nichtig.” Ibid., 479.

78 "Die ungelösten Antagonismen der Realität kehren wieder in den Kunstwerken als die immanenten Probleme ihrer Form.” Ibid., 16.

79 Ibid.

80 “der ästhetische Verstehensbegriff”. (Adorno, 1973, 109).

81 "eine Art von Nachfahren", Ibid. 
the activity of understanding he has in view is irreducible to a fixed hierarchy of concepts. For his theory, the concepts used in commentary and criticism, particularly in the form of writing that is the essay, do not subsume the "matter at issue", Sache, under comprehensive higher concepts but enter into the particular movement of the tensions at work in art. As he puts it in "Der Essay als Form", they do not see through the particular to the general concepts it embodies. Rather, they reflect upon and name the experientially grasped matter at issue in its relation in the individual configuration of form and matter. On the other hand, the essay also cannot be equated with a work of art in its own right. ${ }^{82}$

\section{Appearance, Language, and the Law}

Following Benjamin, Adorno seeks to understand the truth of the work of art as being intimately connected to its "temporal core", Zeitkern. ${ }^{83}$ It partakes, he

82 This is one of the points on which he considers himself as differing from Lukács' early understanding of criticism in Die Seele und die Formen. In Lucács' Florentine letter to Leo Popper of 1910, published under the title "Wesen und Form des Essays" in 1911, he had stated that the essay "faces life with the same gesture as the work of art". ("steht dem Leben mit der gleichen Gebärde gegenüber wie das Kunstwerk”), (Lukács 1971, 31). The question of how justified Adorno's criticism of Lukacs is in this matter cannot be developed here. It should be noted, however, that Lukacs is careful to qualify his comparison and does not equate the critical essay with the work of art tout court. Moreover, Lukács writes: "The essay is a trial but the judgment is not indeed what is essential and decisive with respect to value (as in the system), but rather the process of judging." ("Der Essay ist ein Gericht, doch nicht das Urteil ist das Wesentliche und das Wertentscheidende an ihm (wie im System), sondern der Prozeß des Richtens.”) Ibid. This emphasis on process is close to what we find in Adorno's thought, despite the latter's criticism of Lukacs' position here. Adorno's reflection on Lukacs' early thought accuses him of excessive aestheticism in his treatment of the conceptual component of the essay as form, while in the Ästhetische Theorie and elsewhere he emphatically opposes Lukacs' later advocacy of socialist realism and denunciation of formalism.

83 "If art could rid itself of the illusion of permanence once it has seen through this, if it could incorporate its own transience in sympathy with the ephemeral quality of living things, this would be consonant with a conception of truth that does not consider it as something that perdures abstractly but becomes aware of its temporal core." ("Entschlüge sich Kunst der einmal durchschauten Illusion des Dauerns; nähme sie die eigene Vergänglichkeit aus Sympathie mit dem ephemeren Lebendigen in sich hinein, so wäre das einer Konzeption von Wahrheit gemäß, welche diese nicht als abstrakt beharrend supponiert, sondern ihres Zeitkerns sich bewußt wird.”) (Adorno 1990, 50). 
specifies in the Ästhetische Theorie, in the "secularisation of transcendence". As such, it is involved, he determines, in the dialectics of Enlightenment, and this is why, in contemporary art, the form of anti-Art, Antikunst, continues the work of de-sacralisation. Art that responds to the historical moment points beyond itself, it confronts its own problematic status by configuring its evanescence. Levinas, for his part, seeks to place the work of art in the context of the perspective that ruptures history. He writes in Totalité et infini: "When man really approaches the Other, he is torn out of history". ${ }^{84}$ As will be shown in this section 4 and in section 5 below, Levinas refers this relation explicitly to motifs from the Bible, the Jewish tradition, and sees concrete historical events against this background. When he writes the words, cited in the above, "[s]ubstitution for the other is like the trace of exile and deportation", this is what is at work. In his articles on Agnon and on Celan collected in Noms Propres he poses both the question whether poetry is a form of rhetoric that foments illusion and the question whether it is an "unheard of modality of the autrement qu'être". 85

The relation of subjectivity to Jewish religious tradition informs Levinas's approach to art. Rigorous in his rejection of the sacred, Levinas also repudiates what he refers to as the "desacralized world in which the sacred is still degenerating". 86 The equivalence of the ecstasy of the sacred to the suspension of the law is also found here, in "appearance at the very heart of truth", in "the equivocal that seems to be an enigma". ${ }^{87}$ In order to distinguish what Levinas names

84 "Quand l'homme aborde vraiment Autrui, il est arraché à l'histoire.” Levinas 1980, 23).

85 "une modalité inouïe de l'autrement qu'être". (Levinas 1976, 56). The article "Paul Celan. De l'être á l'autre" quoted here was first published in 1972. 56). While Levinas's article "la réalite et son ombre" makes the term "expression" exclusively the preserve of the ethical in distinction from art, there are passages where this distinction seems less rigorous. An example of this would be his evocation, in the interviews comprising Ethique et infini, of the "literature" that "brings about a rupture in being" (opère une rupture dans l'être), where "through all literature [. . . ] the human face speaks." (à travers toute littérature parle [. . .] le visage humain.). (Levinas 1982, 114). Levinas speaks further of the "eminence of the human face expressed in Greek letters and in our letters that owe everything to them" (l'éminence du visage humain exprimé dans les lettres grecques et dans nos lettres qui leur doivent tout, Ibid., 115) and goes on to say that all national literatures "participate in sacred Scripture" (participation à l'Ecriture sainte dans les littératures nationales, Ibid.). See also the important article "Langage et proximité" and Levinas's discussion of the "extension of tenderness" to language and traced letters: "tenderness extends to all things from the human face and skin" (sur toutes choses, à partir du visage et de la peau humains, s'étend la tendresse). (Levinas 2010, 319).

86 "monde désacralisé, où toujours dégénère le sacré". (Levinas 1977, 121).

87 "apparence au cœur même du vrai”; “les équivoques senties comme des énigmes”. Ibid., 93. 
the "holy" from the "sacred" in his terms, the ramifications of the dissimulating appearance and of the equivocal have to be traced, identified, and opposed. He writes: "The sacred that is degenerating is worse than the sacred that passes away." 88 Levinas is attentive to the gradations of dissimulation that are present in the transformation of the sacred into sorcery. He goes as far as identifying sorcery with this dissimulation, in the epoch of history in which "seeming alters the appearing", 89 with "the modern world". Here "nothing is identical with itself; no one is identical with himself [;] nothing is said, because no word has its proper meaning; every word is a magic afflatus; no one listens to what you say; everyone suspects behind your words the not-said, conditioning, ideology." 90 This is the matter Levinas had in view in his article "La réalite et son ombre" and that art of necessity partakes in because it is apparition. The words with which he asks in "Poésie et resurrection", his article on Agnon, "Are eternity and resurrection through poetry exempt of all illusion? Is the ultimate meaning of the human language and poetry?"91 are written on this background. It is with respect to this question of ultimate meaning that Levinas will discern in Agnon's writing "the indication of an order more ancient than the Saying". ${ }^{92}$ It is in this context that he will discern in Celan's work "the interruption of the ludic order of the beautiful and of the play of concepts and of the play of the world", 93 that he will stipulate the necessity of "a true word", 94 and will identify Celan's trajectory of the poem towards the other as "essentially Jewish". 95 To partake in this is to make appearance submit to a retournement, to the Wende that is also a return and a form of remembrance. It is in this movement, delineated in Autrement qu'être as "the turning from thematisation to an-archy" 96 in

88 "Le sacré qui dégénère est pire que le sacré qui disparaît.” Ibid., 109.

89 "l'apparance altère l'apparaître". Ibid.

90 "La sorcellerie, c'est cela: le monde moderne; rien n'est identique à lui-même; personne n'est identique à lui-même[;] rien ne se dit, car aucun mot n'a son sens propre; toute parole est un souffle magique; personne n'écoute ce que vous dites; tout le monde soupçonne derrière vos paroles du non-dit, un conditionnement, une idéologie.” Ibid., 107-108.

91 "L'éternité et la resurrection par la poésie sont-elles exemptes de toute illusion? La signification ultime de l'humain est-elle langage et poésie?” (Levinas 1976, 19).

92 "l'indication d'un ordre, plus ancien que le Dire". Ibid., Levinas's article "Poésie et résurrection. Notes sur Agnon” was first published in 1973. 20.

93 "l'interruption de l'ordre ludique du beau et du jeu des concepts et du jeu du monde". Ibid., p. 56.

94 "une vraie parole". Ibid., p. 55.

95 “d'essence juive”. Ibid., p. 54.

96 "le retournement de la thématisation en an-archie". (Levinas 1986, 155). 
the approach to the other that Levinas finds an echo of the return to the "order more ancient than the saying".

Levinas enters into this dimension already in his comparatively early thought, when he writes in 1949 in "La transcendence des mots", a meditation on Biffures by Leiris, that "human existence is creature". In this consideration of literature, visual art, and language, which continues his remarks in "La réalité et son ombre", Levinas moves from a determination of what is fixed, frozen, in beauty, be it the visual marks of painting or in the written word, to what is living, contrasting the "frozen words" with the "living word". ${ }^{97}$ He elaborates what the expression, the spoken word that does not close itself in the "spectacle" of the finished work of art, opens up. The "interruption" that takes place here disrupts "my existence as subject and master". 98 The subject becomes herein both subject and object. This differs, however, from the manner in which the subject is situated in a work of art. To be related to the other in the address is a disruption of the position of the subject at the heart of a "spectacle", be this also a subject-object. To be situated with respect to the other, Levinas underlines, is to lose this position. This is due to "the first fact of existence", which is "neither the in itself nor the for itself, but the for the other". 99 This, however, takes Levinas to the point where he states that "human existence is creature". ${ }^{100}$ In a step further he writes: "By the proffered word, the subject that poses itself exposes itself and, in a way, prays."101 The expression "in a way" joins all the other occasions in Levinas's work where the status of an assertion is both maintained and rendered enigmatic.

The association of the enigma with the dimension evoked by the word "pray" is a central aspect of Levinas's later thought. It is important to discern, however, how the act of proffering speech here in this early text, opens up in the particular event of transcendence into a dimension that is always already a source of meaning that suffuses the trace. Levinas's article on Agnon indicates retrospectively how this is possible. In a central passage, he writes of the Hebrew word as ambiguous or enigmatic. With reference to the melitsa, the rhetorical form in which a word evokes Biblical turns of phrase without explicit reference to its doing so, Levinas comments on Agnon's use of this linguistic possibility as "the rupture of a certain ontology". ${ }^{102}$ In this form, "the word

97 “"paroles gelées”; "parole vivante”. (Levinas 1987, 202).

98 "mon existence de sujet et de maître". Ibid., 203.

99 "le fait premier de l'existence n'est ni l'en soi, ni le pour soi, mais le 'pour l'autre”. Ibid.

100 "l'existence humaine est créature". Ibid.

101 "Par la parole proférée, le sujet qui se pose s'expose et, en quelque manière, prie.” Ibid. 102 "la rupture d'une certaine ontologie". Levinas, "Poésie et résurrection”, 13. 
signifies both in the context of the locution in which it is enunciated and, as a counterpoint, according with the Scriptures, points to an unrepresentable past. The enigmatic modality of a language beginning in its own trace!"103 This characterisation of the resurrected trace is elaborated further to encompass the manner in which the liturgical ritual of Judaism suffuses Jewish life and creates "a de-substantialising of being, an excluded third between life and non-life where limits extinguish themselves." ${ }^{104}$ Religion becomes, as Levinas writes, "probable", vraisemblable, where "the nature of things and of beings has issued forth from the symbol". As such, he continues, "the delimitation of their rigorous essence is less true than their symbolism". ${ }^{105}$ He specifies "religion" to mean Judaism. The effect of this interlacing of Jewish life and liturgical rites is radical: "The symbolism of ritual, as the enigma of Jewish saying, extracts the core, the ultimate solidity beneath the plasticity of forms, which is taught by occidental ontology". ${ }^{106}$ In the following development of Levinas's thought in this article, he passes via a reflection on how Agnon can be read as "poésie pure" to the idea that the Jewish life that finds voice here is song that has a meaning of an other kind than as a vehicle for contents. Furthermore, it is not a product of the imagination, not a representation in the form of an image. He writes: "the Unrepresentable will not be represented in the poem. It will be its poetry. Poetry signifies poetically the resurrection that bears it: not in the story that it sings but by its very singing". ${ }^{107}$ This characterisation of poetry, imbued with the meaning Levinas gives to the Saying in Autrement qu'être, undergoes a further twist in Levinas's thought that follows a parallel sense of historical and literary crisis in Agnon's writing. It is a parallel that has its immediate context in the reference to Jewish tradition. "In a world in which living community is disappearing, who will be able to transmit the tradition itself - who will be able

103 "le mot, sans imiter aucun modèle, signifie et dans le contexte du propos où il s'énonce et, en contrepoint, selon les Écritures, pointé vers un passé irreprésentable. Modalité énigmatique d'une langue ressuscitée commençant dans sa propre trace!” Ibid.

104 "une désubstantiation de l'être, un tiers exclu où entre vie et non-vie, les limites s'éffacent". Ibid., 14.

105 "la nature des choses et des êtres est issue du symbole et [. . .] la délimitation de leur rigoureuse essence est moins vraie que leur symbolisme". Ibid.

106 "Le symbolisme du rite, comme l'énigme du dire hébraïque, dénoyaute la solidité ultime sous la plasticité des formes, qu'enseigne l'ontologie occidentale.” Ibid.

107 "l'Irreprésentable ne sera pas représenté dans le poème. Il en sera la poésie. La poésie signifie poétiquement la résurrection qui la porte: non pas dans la fable qu'elle chante, mais par son chanter même.” Ibid., 17. 
to read the scriptures?" 108 The fragility of this tradition lays bare the nature of poetry. Levinas interprets Agnon's story “The Seal” in which Ibn Gabirol, the dead poet, composes a poem for the person mourning the community exterminated in his native town. Transported by the poem, the living poet forgets its words. Levinas's comment on this cuts to the quick of literature and the modernity to which it responds. "The mortality of tradition reveals the rhetoric that poetry - this last refuge of transcendence in occidental humanism - dissimulates."109 The fear that Agnon expresses in the story is ultimately that the literature that could resurrect the moribund Jewish tradition is facing its end, for this literature is confronted with the crisis of occidental humanism. In his comments, the step that Levinas takes with respect to this crisis is crucial, and the context in which he places them serves as a touchstone for the possibility of finding meaning even in the recent historical Jewish experience of being subjected to industrial murder, which indicates a complete absence of meaning. Even here Levinas avers that there is in Agnon's story "perhaps [. . . ] the indication of an order more ancient than Saying, through which the non-sense of death can be contested". ${ }^{110}$ This order is embodied in the Tora and its injunction of the Law of justice and love for the other. The "perhaps" with which Levinas begins this comment joins the "in a way" in "La transcendence des mots" cited earlier. As Levinas's final remarks on Agnon underline, death still bears within it the "mystery" of its "meaningless meaning", which can never be restricted by comprehending it within the limits of life. This is its "surplus", ever surpassing the limits and, Levinas submits, "exalting life". ${ }^{111}$ While literature can engage with the trace, can be remembrance of that which withdraws from reminiscence, Levinas's comments here and in his article on Leiris show that this is constantly in question. For Levinas to reveal that Leiris falls short because he subordinates expression to thought, making it part of the communication of thought, and for him to refer to the "rhetoric" of poetry, which is the last refuge of transcendence in humanism, indicates that he continually subjects literary language to the rigorous criterion of rendering the echo of the Saying in the works created.

108 "Dans un monde où disparait la communauté vivante, qui pourra transmettre la tradition elle-même - qui pourra lire les écritures?” Ibid., 19.

109 "La mortalité de la tradition révèle la rhétorique que dissimule la poésie - cet ultime réduit de la transcendance dans l'humanisme occidental.” Ibid.

110 "peut-être [. . . ] l'indication d'un ordre, plus ancient que le Dire, par lequel le non-sens de la mort se conteste". Ibid., 20.

111 "sens insensé”; "surplus"; "exalte la vie”. Ibid., 21 passim. 
It is a remembrance related to this language of the echo that Adorno has in view when he explores art as Mnemosyne, as that which expresses the paradox in the work of art as being what is evanescent and that which maintains itself. This takes place in various ways. The work of art is both the surpassing of the chthonic tremor, in the forming process of Enlightenment as truth, and the maintenance of the sense of what was overcome. It is the evanescence of the apparition as that which comes to be and passes away, which withdraws itself in the instant, but which is at the same time "expressive appearance". ${ }^{112}$ Anamnesis enters into the trace of this expression. It seeks to make it speak. In order to reveal what is required by this anamnesis, Adorno undertakes a rigorous critique of theories that infer aesthetic realism from philosophical materialism. He argues against the conception of Mimesis that requires the work of art to imitate the reality that it finds outside itself. The aim of providing a "photographic" reproduction of an "outside" reality delivers the work of art up to a heteronomy that deprives it of its own way of knowing truth. In contrast to this, Adorno seeks to reveal a dialectic at work in which both the autonomy of the work of art and its particular opening onto reality are maintained. He does this be adumbrating a structure of immanence in which the complexity of the moments comprising it is bound by a tension that pushes it out and beyond itself. The work of art, just as the subject, according to Adorno's argument, is “socially mediated within itself". ${ }^{113}$ The concentration of the work of art on itself and on the formal problems that present themselves therein individuates it. This concentrated configuration embodies at the same time a position taken in a specific historical moment to the reality that lies outside it. If Adorno writes "[a]rt has its other [. . .] in its immanence", 114 then it is because transcendence takes place in its "own procedure", ${ }^{115}$ orientated towards "objectivation". It is form that carries out transcendence.

Adorno thematises the dialectical movement that takes place here as language. With respect to art, he writes: "It has to bring its latent social content to speak: to go inside itself in order to go out beyond itself."116 The idea of calling forth the language latent in something is a theme that is encountered in other important related contexts in Adorno's Ästhetische Theorie. To take a salient example, he writes in the section of his work devoted to the aesthetic theory of

112 “ausdrückende[. . . ] Erscheinung”. (Adorno, 1990, 126).

113 "in sich gesellschaftlich vermittelt". Ibid., 386.

114 "Kunst hat ihr Anderes [. . .] in ihrer Immanenz" Ibid.

115 "eigene[. . .] Verfahrensweise". Ibid.

116 "Zum Sprechen bringen muß sie ihren latenten gesellschaftlichen Gehalt: in sich hineingehen, um über sich hinauszugehen." Ibid. 
natural beauty that the immanent structure of the work of art is what enables one to bring nature, which is mute, to speak. Against Hegel's argument in his lectures on aesthetics that the idea of beauty cannot be applied to natural objects but only to artefacts, Adorno argues that it is possible to experience nature in a way that neither deforms it as myth does nor reifies it as a mere material resource to be exploited. To wish to imitate nature in the work of art renders it vulnerable to both of these aberrations. The experience of nature embodied in the work of art that Adorno conceives in contrast to this is one in which the human sensuous engagement with the material world elicits a response from it by transforming it. He writes: "Art seeks to realise the speaking of the nonhuman by using human means." 117 Adorno develops this idea as a precise formal correlation to the dialectical structure he delineates with regard to the social content of the work of art.

It is from the perspective of the philosophy of history that Adorno examines language, situating it with regard to the human emergence from myth and with the attendant change in the relation to nature. This stratum of his thought on language is represented in the work Dialektik der Aufklärung. In an undated text, which, however, probably stems from the beginning of the thirties, Adorno writes in a reflection on Max Scheler's philosophy: “All deceptive ontology must be exposed particularly through the critique of language."118 This sentence, which could equally be found both in the early and the later Wittgenstein, is the culmination of a series of theses in which Adorno elaborates the connection of language with history, with the concrete historical moment. The seventh thesis, which in the thought of "Konfiguration" points to Adorno's use of this term with regard to the work of art thirty years later in the Ästhetische Theorie, exemplifies this tendency. Adorno writes: "Today, the philosopher is confronted with disintegrated language. His material consists of the ruins of words, to which history binds him; his freedom consists merely in the possibility of configuring them according to the coercive force of truth in them. He may as little think a word as predetermined as he may invent one."119 The configuration that takes its point of departure in the subject is nevertheless orientated towards the "coercive force of truth" that inhabits words. If the

117 "Kunst möchte mit menschlichen Mitteln das Sprechen des nicht Menschlichen realisieren.” Ibid., 121.

118 “Alle trügende Ontologie ist sprachkritisch zumal zu entlarven.” (Adorno, 1969, 371).

119 "Es steht heute der Philosoph der zerfallenen Sprache gegenüber. Sein Material sind die Trümmer der Worte, an die Geschichte ihn bindet; seine Freiheit ist allein die Möglichkeit von deren Konfiguration nach dem Zwange der Wahrheit in ihnen. Er darf so wenig ein Wort als vorgegeben denken wie ein Wort erfinden.” Ibid., 368-369. 
philosopher may neither regard a word as being "predetermined" nor as something he can invent, this passage marks the place in which Adorno will later insert the thought of dialectic. He will denote this as yet still empty space as the locus of mediation.

\section{The Play of Mirrors, the Cage, and Aesthetic Responsibility}

"It is not fortuitous that the dissolution of reality that had become song grew, in Cervantes' prose, into the lightness filled with suffering of great epic narrative" ${ }^{120}$ - Georg Lukacs' analysis of epic form from the perspective of the philosophy of history is not only seminal for Benjamin and Adorno, but it marks the epochal confrontation of interiority with the other and with the demonic that is at issue in art for Levinas and Kafka. In Totalité et infini, Levinas writes of the "rectitude", droiture, of the relation to the other that characterises the "face-to-face", face à face. Here he writes that this is not "a play of mirrors"121 but "my responsibility". To consider art as more than a play of mirrors, with respect to which Levinas maintains a constant suspicion, requires a reflection on its relation to responsibility.

Levinas weaves the question of appearance, disproportion, and the work of art together in a meditation on Don Quixote, identifying Cervantes' picaresque novel - in a parallel to Descartes' exposition of the cogito and the threat of the Malin Génie - as a crucial expression of modern man's fear of the spell of bewitchment. The trajectory of Levinas's reflection is made evident when he writes "In truth, only God is the metaphor that suffices to say the disproportion." ${ }^{\text {"122 }}$ His focus on Don Quixote is part of an analysis of secularisation understood as the combat between the search for truth and the spell of myth. It is an analysis that should be compared in detail with that of Horkheimer and Adorno on the Enlightenment. Levinas's consideration of technology here as the "destroyer of the gods of the world and of the god-things" 123 indicates that

120 "Es ist kein Zufall, daß das Zerfallen der liedgewordenen Wirklichkeit in Cervantes’ Prosa zur leiderfüllten Leichtigkeit der großen Epik erwuchs [. . .].” (Lukács, 1975, 50).

121 "Ce n'est pas un jeu de miroirs, mais ma responsabilité, c'est-à-dire une existence déjà obligée.” (Levinas, 1980, 158).

122 “À vrai dire, seul Dieu est métaphore suffisante pour dire la dis-proportion." (Levinas, 1993, 195).

123 “déstrutrice des dieux du monde, des dieux-choses”, Ibid., 196. 
although it serves to counter the spell of myth it is also liable to mystification. Both technology and the attempts at sobriety and rigour in the humanities are vulnerable inasmuch as they can become ideology. Levinas states, however, evoking Genesis 1:3, that it is above all technology that falls prey to "the possibly seeming that lies coiled in all appearing". ${ }^{24}$

In an exegesis beginning with Chapter XLVI in the first part of Don Quixote, Levinas first shows how the eponymous knight attempts to convince those surrounding him that the everyday figures who have confined him in a cage in order to bring him back to his village are really spirits and that everyone has been put under a spell. Sancho Pansa is depicted as recognising the delusion to which his master has fallen prey. In a radical interpretation of Don Quixote's “imprisonment within the labyrinthine spell", ${ }^{125}$ Levinas contends that he undergoes an experience of the cogito at the heart of this illusion. In the words that Don Quixote says with regard to his experience of certainty Levinas discerns what he denominates "an other secularisation", ${ }^{126}$ to which the awareness of, and openness to, the hunger of others and the vulnerability and exigencies of the lived body responds. Levinas interprets this as a transcendence that is "nonontological or at least would not have its origin or its measure in ontology". ${ }^{27}$ The parallel he sets up here is trenchant: "Ontology reduces the visible gods but it would place us in the position of Don Quixote and of his labyrinthine imprisonment if there were not this other transcendence". ${ }^{128}$ In the words of Don Quixote, where the imprisoned knight says that he knows that he is under a spell and that if this were not the case it would be cowardly to be hiding in a cage while others are afflicted and in need of his help, Levinas discerns "in the humility of hunger" an opening. It is a "non-ontological transcendence that begins in the lived bodies of men." 129 He underlines that it is in this movement and "[o]nly in this movement that goes towards the other man"130 that responsibility is primarily to be found.

124 "l'apparance possible qui se love dans tout apparaître de l'être”. Ibid.

125 "enfermement dans l'enchantement labyrinthique”. Ibid., 197.

126 "une autre sécularisation”. Ibid., 198.

127 “ [. . . ] non ontologique ou du moins non trouvant pas son origine ni sa mesure dans l'ontologie.” Ibid., 198.

128 "L'ontologie réduit les dieux visibles, mais elle nous placerait dans la position de Don Quixote et de son enfermement labyrinthique s'il n'y avait pas cette autre transcendance." Ibid.

129 "une transcendence non ontologique qui commence dans la corporéité des hommes". Ibid.

130 "Seulement dans un movement qui va vers l'autre homme et qui est d'emblée responsabilité.” Ibid. 
Within the text of Don Quixote and within the figure of the imprisoned knight, at the heart of illusion, a non-spatial exteriority is opened. In hunger a second secularisation of the world takes place, and it is in this, in its extremity, that an appeal is issued to subjectivity. Using the terms of Autrement qu'être, it is in subjectivity, the sensibility of the subject to the hunger of the other, that "substitution" takes place. The experience in question is profoundly enigmatic. Levinas writes: "Secularisation through hunger is a question on God and to God - and thus at the same time more and less than an experience. It is a pre-orational question, a question without a response and like an enigmatic or ambiguous echo of the question. One will have to be more specific and say that with this analysis it is not a case of subjectivising transcendence but of being astonished by subjectivity."131

With regard to Don Quixote as a work of art, Levinas hence elucidates an immanent complexity and tension that, in a parallel to Adorno's analysis of the monadic tensions in modern art, opens a fissure within representation. One could refer to this not only as depicted responsibility, but as itself embodying the responsibility that is possible for the work of art in engaging with appearance by challenging it.

Such a possibility can be found in Kafka's Nachlaß text that bears the title, conferred by Max Brod, "Die Wahrheit über Sancho Pansa”. In his essay on Kafka of 1934, Benjamin comments on this text in the context of his discussion of Bucephalus and of the studying - in contrast to the practice - of the Law. The "gates of justice"132 are constituted by the Law as studied and not as practiced. In Benjamin's reading, Kafka could not envisage the promise that tradition attached to the Tora. Hence, Benjamin writes, the figures of the assistants and the students in his work (in Das Schloß and Amerika respectively) are detached from what would otherwise be their place in Jewish life, where the former would be serving the community in the synagogue and the latter would be learning the Tora. The text by Kafka bearing the title "Die Wahrheit über Sancho Pansa" was written in 1917, at a time when Kafka was considering the publication of a collection of stories under the title Verantwortung, Responsibility. Benjamin's introductory comment on this text is singular in the degree of his estimation for this short piece. He writes that in contrast to

\footnotetext{
131 "La sécularisation par la faim est question sur Dieu et à Dieu - et ainsi à la fois plus et moins qu'une expérience. Elle est question pré-orationnelle, question sans réponse, et comme un écho énigmatique ou ambigu de la question. On précisera cependant qu'avec cette analyse il ne s'agit pas de subjectiviser la transcendance, mais de s'étonner de la subjectivité.” Ibid., 199-200.

132 "Pforte der Gerechtigkeit”. (Benjamin 1991, 437).
} 
the "empty happy journey" that the Gehilfen and the Studenten were now free to begin, Kafka found the law, Gesetz, of his own. He was able "at least one sole time" to slow down the "breathtaking speed" of this journey and make it conform to "an epic walking pace". ${ }^{133}$ In other words, this is a Haggada that modifies the Halacha. Benjamin writes: "He entrusted it to a text, which became his most accomplished, not least because it is an exegesis". ${ }^{134}$ To compare Kafka's exegesis with Levinas's commentary on Don Quixote is to encounter a further turn in the question of the responsibility of the work of art with respect to apparition.

"Die Wahrheit über Sancho Pansa" consists of two sentences, both of which begin with the words "Sancho Pansa". In the first sentence, the action carried out by the subject Sancho Pansa, which consists of providing a quantity of novels of chivalry and of brigandage, Ritter- und Räuberromane, and thereby distracting his devil from him and rendering it harmless, is broken up by a series of relative clauses. These slow the pace and become a labyrinthine syntactical structure. The action is in effect carried out by the literature. Its function is to divert the harm that the unconstrained, unrooted, haltlos, devil could do in objectifying the subject. As in the story "Das Schweigen der Sirenen", which Kafka wrote into the third Oktavheft three days after inscribing "Die Wahrheit über Sancho Pansa" there, the text centres on a medial procedure employed by men to escape harm from mythical forces. Both involve foresight, preparation, and strategy involving technical means. In the case of Sancho Pansa, these consist of narrative, the provision of form for what would be otherwise random events, and the creation of worlds of the imagination. As far as the subject of the second story, Odysseus, is concerned, "childlike means", kindische Mittel, are employed to effect "salvation", Rettung. While the means may be "childlike”, they involve strategic planning.

In the second sentence, the devil is referred to as Don Quixote. The change that consists in the denomination is mentioned in a relative clause that constitutes one of turns in the syntax of the first sentence. This change is, however, not innocent. There is one sole reference to "Don Quixote" and this is in the form "dem Don Quixote”, which in this locution has the function of familiarisation in the German language. By doing this, the language itself does what the

133 'Nun hält sie nichts mehr auf der 'leeren fröhlichen Fahrt'. Kafka hat aber das Gesetz der seinen gefunden: ein einziges Mal zumindest, als es ihm glückte, ihre atemraubende Schnelligkeit einem Paßschritt anzugleichen, wie er ihn wohl sein Lebtag gesucht hat.” Ibid.

134 "Er hat es einer Niederschrift anvertraut, die nicht nur darum seine vollendetste wurde, weil sie eine Auslegung ist." Ibid. 
object referred to is: it expresses the fact that "Don Quixote" is a "familiar", a personal demon.

The subject of the second sentence, Sancho Pansa, is immediately qualified as "a free man", and the sentence goes on to describe his relation to the devil, "Don Quixote". He "followed”, folgte, Don Quixote's riotous deeds "with equanimity", gleichmütig, and - crucially - "perhaps out of a feeling of responsibility". 135 Finally, the reader is told that Sancho Pansa derived from this "great and useful entertainment". ${ }^{136}$ The objectification of the devil as "Don Quixote" is thus characterised with an epithet that looks very much like the Horatian prodesse et delectare with which the task of literary art was characterised in a certain tradition.

Kafka's text is a mise-en-scène of the replacement of the practice of appeasement and expiation with respect to mythic or demonic forces by the techniques of the imagination. No longer in thrall to the spell cast by myth, the subject as "a free man" can follow the disruptive forces from the distance afforded by this replacement. To do this "perhaps out of a feeling of responsibility" is to retain the memory of what the possibilities realised by the imagination have overcome. If Benjamin can write of "Die Wahrheit des Sancho Pansa" that it is Kafka's "most accomplished, not least because it is an exegesis", he is according it the seriousness similar to that of the commentary of a holy text. This is how he himself characterised his own commentaries on Brecht. In Kafka, it constitutes a radical further step in the inversion of appearance that Levinas's commentary on Don Quixote contains. In Cervantes' work, Don Quixote imagines that the barber, the priest, and those who accompany them are spirits and that everyone, himself included, is under a spell. Levinas enters into the labyrinth of Don Quixote's immanence to find the moment of fissure that inverts the appearance and opens to the other. In Kafka, one twist further, Sancho Pansa, who is an imagined figure, frees himself from the thrall of Don Quixote, who is also an imagined figure, by using the techniques of the imagination provided by narrative. Imagination, turning further into itself, provides the moment of fissure. In both cases, apparition in the work of art points beyond itself as a kind of disproportion. For Levinas, the affliction of the other calls forth from within the illusion. For Kafka, the liberation from the devil in the play of the imagination shifts, as Benjamin writes, the tectonic plates of world-epochs. Levinas states in "Désacralisation et désensorcellement": "Veritable de-sacralisation would try to separate positively what is true from appearance, perhaps to separate what is

135 "vielleicht aus einem gewissen Verantwortlichkeitsgefühl”. Ibid., 438.

136 “eine große und nützliche Unterhaltung”. Ibid. 
true from the appearance essentially mixed with truth." 137 If this is the case, the work of imagination, as in Kafka's text, can embody and realise discernment, krinein, the separation that is the task of critique. It is necessary to think Levinas's determinations of responsibility in art further in the light of such evocations of apparition and aesthetic disproportion as realised in "Die Wahrheit des Sancho Pansa”. The exegesis of Don Quixote by both Levinas and Kafka reveals how responsibility can be embodied in the work of art as vigilance in the labyrinth of apparition.

In Adornos's comprehensive Introduction to his central work on Husserl's thought, Zur Metakritik der Erkenntnistheorie, published in 1956, he delineates crucial ways in which the "idea of philosophical critique" that he opposes to the concepts of epistemology inherited from tradition opens up the possibility of transformative praxis. Here, as in his later important article "Voraussetzungen" of 1961, he distinguishes between the concepts in which scientific semantics translates language into logic, on the one hand, and the speculative philosophy and semantics that "would make logic speak", ${ }^{138}$ on the other hand. It is not fortuitous that in both of these loci in Adorno's work the movement in which objectifying thought is brought to a point beyond itself, undermining its own claim to dominance, is traced in intimate proximity to his exploration of how works of art enact meaning. It is also not fortuitous that Adorno connects in both the analysis of the surpassing of objectifying cognition and of linguistic meaning that goes beyond the fixed semantics of concepts with the ideas of "unconscious historiography", of remembrance, and of suffering that play such a important role in his Ästhetische Theorie.

In the Introduction to his Metakritik, Adorno writes, echoing Marx and Benjamin, "If the epoch of the interpretation of the world has passed and it is now the task to change it, philosophy takes its departure, and in departure concepts stand still and become images." brings these images to life and makes them speak by tracing the movement configured within them. This is the perspective in which Adorno, for his part, approaches Kafka, revealing how Kafka pushes the logic of the distorted world that he encounters to its limits and by doing so undermines these through a kind of

137 "La véritable désacralisation tenterait de séparer positivement le vrai de l'apparence, peutêtre même de séparer le vrai de l’apparence essentiellement mêlée au vrai.” (Levinas 1977, 90).

138 "die Idee philosophischer Kritik”; “die Logik zum Sprechen zu bringen”. (Adorno, 1971, 47). 139 "Ist das Zeitalter der Interpretation der Welt vorüber und gilt es [,] sie zu verändern, dann nimmt Philosophie Abschied, und im Abschied halten die Begriffe inne und werden zu Bildern." Ibid. 
mimicry. The dialectic that Adorno sees enacted here is such that Kafka corroborates the claims of the world on the subject to the point that they turn against themselves. For Adorno, Kafka seeks salvation by incorporating the power of the world of mythical forces, opposing the reification that has cast its spell on the subject by himself reifying the subject in his work, bringing myth to deconstruct itself in its mirror-image. In revealing the ways in which Kafka's writing employs this cunning, with which he seeks to reconcile myth, Adorno seeks to trace in his work the kind of responsibility that art enacts. Adorno rejects the translation of Kafka's writing into philosophical propositions that would be expressed in concepts. At the end of his article "Voraussetzungen", he explores the manner in which the hermetic works of art of modernity form within themselves the breach between the work of art and the world. By pushing the conflict between subjective expression and meaning grasped in concepts to the extreme, the work "loving and hoping" - makes of the breach the agent of the work's form and the figure of the truth-content that transcends it. To discern this movement in the work of art is the task of the critic; to embody this figure is, for Adorno, the responsibility of the work of art.

\section{Bibliography}

Adorno, Theodor W.. "Die Aktualität der Philosophie”. Philosophische Frühschriften. Gesammelte Schriften, Vol. 1. Ed. Rolf Tiedemann. Frankfurt am Main: Suhrkamp, 1973 (1931). 325-344.

Adorno, Theodor W.. "Thesen über die Sprache des Philosophen". Philosophische Frühschriften. Gesammelte Schriften, Vol. 1. Ed. Rolf Tiedemann. Frankfurt am Main: Suhrkamp, 1969. 366-371.

Adorno, Theodor W.. Kierkegaard. Konstruktion des Ästhetischen. Gesammelte Schriften, Vol. 2. Ed. Rolf Tiedemann. Frankfurt am Main: Suhrkamp, 1979 [1933].

Adorno, Theodor W.. Zur Metakritik der Erkenntnistheorie. Gesammelte Schriften. Vol. 5. Eds. Gretel Adorno and Rolf Tiedemann. Frankfurt am Main: Suhrkamp, 1971 [1956].

Adorno, Theodor W.. “Der Essay als Form”. Noten zur Literatur. Gesammelte Schriften, Vol. 11. Ed. Rolf Tiedemann. Frankfurt am Main: Suhrkamp, 1991 [1958]. 9-33.

Adorno, Theodor W.. "Voraussetzungen. Aus Anlaß einer Lesung von Hans H. Helms”. Versuch, das Endspiel zu verstehen. Frankfurt am Main: Suhrkamp, 1973 [1961]. 107-126.

Adorno, Theodor W.. Ästhetische Theorie. Gesammelte Schriften, Vol. 7. Ed. Rolf Tiedemann. Frankfurt am Main: Suhrkamp, 1990 [1970].

Benjamin, Walter. "Franz Kafka. Zur zehnten Wiederkehr seines Todestags”. Gesammelte Schriften. Vol. II,2. Eds. Rolf Tiedemann and Hermann Schweppenhäuser. Frankfurt am Main: Suhrkamp, 1991 [1934, (409-432)]. 409-438.

Benjamin, Walter. Briefe. Eds. Gershom Scholem and Theodor W. Adorno. Frankfurt am Main: Suhrkamp, 1966. 
Benjamin, Walter. Das Passagen-Werk. Gesammelte Schriften, Vol. V,1. Ed. Rolf Tiedemann. Frankfurt am Main: Suhrkamp, 1982.

Céline, Louis-Ferdinand. Voyage au bout de la nuit. Paris: Gallimard, 1952 [1932].

Céline, Louis-Ferdinand. Nord. Paris: Gallimard, 1960.

Ciaramelli, Fabio. "L'appel infini à l'interprétation. Remarques sur Levinas et l'art". Revue philosophique de Louvain XCII (1994): 32-52.

Colleony, Jacques. "Levinas et l'art: La réalité et son ombre”. La part de l'œil 7(1991): 81-90.

Ginzburg, Carlo. Das Schwert und die Glühbirne. Picasso's “Guernica”. Frankfurt am Main: Suhrkamp, 1999.

Kafka, Franz. “Die Wahrheit über Sancho Panza”. Sämtliche Erzählungen. Ed. Paul Raabe. Frankfurt am Main: Fischer, 1970 [1931]. 304.

Levinas, Emmanuel. De l'évasion. Paris: Le livre de poche, 1982 [1935].

Levinas, Emmanuel. De l'existence à l'existant. Paris: Vrin, [1947].

Levinas, Emmanuel. Le temps et l'autre. Paris: PUF, 1983 [1948].

Levinas, Emmanuel. "La réalité et son ombre". Les imprévus de l'histoire. Montpellier: Fata Morgana, 1994 [1948]. 123-148.

Levinas, Emmanuel. “La transcendence des mots”. Hors sujet. Paris: Le livre de poche, 1987. [1949]. 197-203.

Levinas, Emmanuel. “Enigme et phénomène”. En découvrant l'existence avec Husserl et Heidegger. Paris: Vrin, 2010 [1949]. 283-302.

Levinas, Emmanuel. “Personnes ou figures (À propos d' 'Emmaüs' de Paul Claudel). Difficile Liberté. Essais sur le judaïsme. Paris: Le livre de poche 1976 [1950]. 184-189.

Levinas, Emmanuel. “L’arche et la momie”. Difficile Liberté. Paris: Le livre de poche, 1976 [1958]. 90-92.

Levinas, Emmanuel. Totalité et infini. The Hague: Nijhoff, 1980 [1961].

Levinas, Emmanuel. “La poésie et l’impossible”. Difficile Liberté. Essais sur le judaïsme. Paris: Le livre de poche, 1976 [1969]). 196-204.

Levinas, Emmanuel. "Simone Weil contre la Bible". Difficile Liberté. Essais sur le judaïsme. Paris: Le livre de poche, 1976 [1963]. 205-217.

Levinas, Emmanuel. “Intentionalité et métaphysique”. En découvrant l'existence avec Husserl et Heidegger. Paris: Vrin 2010 [1969]. 189-200.

Levinas, Emmanuel. "La trace de l'autre”. En découvrant l'existence avec Husserl et Heidegger. Paris: Vrin 2010 [1969]. 261-282.

Levinas, Emmanuel. Autrement qu'être ou au-delà de l'essence. Dordrecht: Martinus Nijhoff, 1986 [1974].

Levinas, Emmanuel. “Max Picard et le visage”. Noms Propres. Paris: Le livre de poche, 1976 [1975]. 111-116.

Levinas, Emmanuel. "Poésie et resurrection. Notes sur Agnon”. Noms Propres. Paris: Le livre de poche, 1976 [1975]. 11-21.

Levinas, Emmanuel. "Dieu et l'Onto-théologie”. Dieu, la mort et le temps. Paris: Le livre de poche, 1993 (1975/76). 137-279.

Levinas, Emmanuel. “Désacralisation et désensorcellement”. Du sacré au saint. Paris: Les editions du Minuit, 1977. 82-121.

Levinas, Emmanuel. “Façon de parler”. De Dieu qui vient à l'idée. Paris: Vrin, 1986 [1980]. 266-270.

Levinas, Emmanuel. “Langage quotidien et rhétorique sans eloquence”. Hors sujet. Paris: Le livre de poche, 1987 [1981]. 183-193. 
Levinas, Emmanuel. Éthique et infinie. Dialogues avec Philippe Nemo. Paris: Le livre de poche, 1982.

Lukács, Georg. Die Seele und die Formen. Neuwied/Berlin: Luchterhand, 1971 [1910]. Lukács, Georg. Theorie des Romans. Neuwied/Berlin: Luchterhand, 1975 [1916].

De Vries, Hent. Minimal Theologies. Critiques of Secular Reason in Adorno and Levinas. Baltimore: Johns Hopkins University Press, 2005. 